No. 1-2

Recent Progress in Epithelial-Mesenchymal Transitions. Development - Cancer Pathology

Guest Editors: Donald F. Newgreen; Erik W. Thompson (Melbourne)

5 Preface

Newgreen, D.F.; Thompson, E.W. (Melbourne)

11 Transforming Growth Factor- $\beta$ Signaling during Epithelial-Mesenchymal Transformation: Implications for Embryogenesis and Tumor Metastasis Nawshad, A. (Lincoln, Nebr.); LaGamba, D. (Boston, Mass.); Polad, A. (Lincoln, Nebr.); Hay, E.D. (Boston, Mass.)

24 Regulatory Mechanisms for Neural Crest Formation Sakai, D.; Wakamatsu, Y. (Sendai)

36 Mesenchymal-to-Epithelial Transition during Somitic Segmentation: A Novel Approach to Studying the Roles of Rho Family GTPases in Morphogenesis Takahashi, Y. (Kobe/Nara); Sato, Y.; Suetsugu, R. (Kobe); Nakaya, Y. (Kobe/Nara)

43 Transforming Growth Factor- $\beta$-Induced Epithelial-Mesenchymal Transition in the Lens: A Model for Cataract Formation de Iongh, R.U. (Melbourne); Wederell, E.; Lovicu, F.J.; McAvoy, J.W. (Sydney)

56 Invasion and Metastasis in Colorectal Cancer: Epithelial-Mesenchymal Transition, Mesenchymal-Epithelial Transition, Stem Cells and $\beta$-Catenin

Brabletz, T.; Hlubek, F.; Spaderna, S.; Schmalhofer, O.; Hiendlmeyer, E.; Jung, A.; Kirchner, T. (Erlangen)

66 Hyaluronan: A Critical Component of Epithelial-Mesenchymal and EpithelialCarcinoma Transitions

Toole, B.P.; Zoltan-Jones, A.; Misra, S.; Ghatak, S. (Charleston, S.C.)

73 The Src-Induced Mesenchymal State in Late-Stage Colon Cancer Cells Avizienyte, E.; Brunton, V.G.; Fincham, V.J.; Frame, M.C. (Glasgow)

81 A Perspective on Regulation of Cell-Cell Adhesion and Epithelial-Mesenchymal Transition: Known and Novel

Khew-Goodall, Y.; Wadham, C. (Adelaide)

87 Author Index Vol. 179, No. 1-2, 2005

87 Subject Index Vol. 179, No. 1-2, 2005

88 Patent Watch

89 Conference Calendar 
No. 3

Original Papers

91 Milieu-Adopted in vitro and in vivo Differentiation of Mesenchymal Tissues Derived from Different Adult Human CD34-Negative Progenitor Cell Clones

Moosmann, S.; Hutter, J.; Moser, C.; Krombach, F.; Huss, R. (München)

102 Expression of the CD44 Receptor in the Blood Vessel System: An Experimental Study in Rat Hellström, M.; Engström-Laurent, A.; Hellström, S. (Umeå)

109 Concerted Upregulation of CLP36 and Smooth Muscle Actin Protein Expression in Human Endometrium during Decidualization

Miehe, U.; Neumaier-Wagner, P.; Kadyrov, M. (Aachen); Goyal, P. (München); Alfer, J.; Rath, W.; Huppertz, B. (Aachen)

115 Novel Metal Clusters Isolated from Blood Are Lethal to Cancer Cells

Samoylov, A.M.; Samoylova, T.I.; Pustovyy, O.M.; Samoylov, A.A.; Toivio-Kinnucan, M.A.; Morrison, N.E.; Globa, L.P.; Gale, W.F.; Vodyanoy, V. (Auburn, Ala.)

125 Hamstring Muscles: Architecture and Innervation

Woodley, S.J.; Mercer, S.R. (Dunedin)

142 Patent Watch

143 Conference Calendar

\section{No. 4}

145 Editorial

Denker, H.-W. (Essen); English, A.W. (Atlanta, Ga.)

Original Papers

146 Meckel's Cartilage Differentiation Is Dependent on Hedgehog Signaling Melnick, M.; Witcher, D.; Bringas, P. Jr. (Los Angeles, Calif.); Carlsson, P. (Göteborg); Jaskoll, T. (Los Angeles, Calif.)

158 Fibrin Gel-Immobilized Primary Osteoblasts in Calcium Phosphate Bone Cement: In vivo Evaluation with Regard to Application as Injectable Biological Bone Substitute Kneser, U. (Freiburg/Erlangen); Voogd, A.; Ohnolz, J.; Buettner, O.; Stangenberg, L.; Zhang, Y.H.; Stark, G.B. (Freiburg); Schaefer, D.J. (Freiburg/Basel)

170 Manipulation of the Phenylalanine Metabolism in Human Keratinocytes by Retroviral Mediated Gene Transfer

Christensen, R.; Kolvraa, S. (Aarhus); Jensen, T.G. (Glostrup)

179 Structure of the Ovaries of the Nimba Otter Shrew, Micropotamogale lamottei, and the Madagascar Hedgehog Tenrec, Echinops telfairi

Enders, A.C. (Davis, Calif.); Carter, A.M. (Odense); Künzle, H. (München); Vogel, P. (Lausanne)

192 Relationship between Pituitary and Adipose Tissue after Hypothalamic Denervation in the Female Rat. A Morphometric Immunohistochemical Study

Camihort, G.; Gómez Dumm, C.; Luna, G.; Ferese, C.; Jurado, S.; Moreno, G.; Spinedi, E.; Cónsole, G. (La Plata)

202 Patent Watch

203 Conference Calendar

205 Author Index Vol. 179, 2005

206 Subject Index Vol. 179, 2005 